\title{
Immunoglobulins in Jamaicans and Nigerians with immunogenetic typing of myeloma and lymphoma in Jamaicans
}

\author{
H. McFARLANE, A. TALERMAN 1 , AND A. G. STEINBERG \\ From the Department of Chemical Pathology, University of Ibadan, Nigeria, and of Pathology, \\ University of the West Indies, Kingston, Jamaica, and the Department of Biology, Case Western \\ Reserve University, Cleveland, Ohio, USA
}

SYNOPSIS Serum IgG concentration was lower in Jamaicans than in Nigerians. The maternatfoetal IgG ratio was also lower in Jamaican sera than in Nigerian sera. It is suggested thæ्षt endemic malaria in Nigeria may be responsible for these differences. The higher IgM concentrô tion in the Nigerian cord sera may be further evidence of this. Eighteen new cases of myeloma were detected in Jamaicans between August 1966 and May 1967. Based on Gm typing, onథ two of these showed evidence of mixed white ancestry. All the others had the typical G groups of Negroes. Similarly, only two patients out of a total of 17 with malignant lymphon showed evidence of mixed white ancestry. Twelve of the patients with myeloma showed seru确 proteins of the IgG type, five were IgA, and one had only light chains in the serum. The majority of the patients had myeloma protein of the kappa type. The Gm typing suggested that six patients had myeloma protein of the $\gamma 1$ heavy chain subclass, and one patient had a $\gamma 3$ subclass heavy chain, the remainder belonging most likely to the $\gamma 2$ heavy chain subclass since $\gamma 2$ occurs about four times as frequently as $\gamma 4$.

The last five years have seen great advances in the study of the immunoglobulins in health and disease and one of the first diseases in which they were studied was multiple myeloma. This disease is very uncommon in those parts of Africa populated by Negroes (Camain and Lambert, 1964; Davies, 1964; Edington and MacLean, 1964) while in the American Negro its incidence is much higher than in white Americans (MacMahon and Clark, 1956). The incidence of multiple myeloma is also high in Jamaicans (McFarlane, 1966; Talerman, 1968). Various reasons have been advanced for the higher levels of gamma globulin in Africans than in Caucasians (Mohun, 1946; Edozien, 1957).

\section{Materials and Methods}

Blood was obtained from 150 Jamaican and

${ }^{1}$ Present address: Institute of Pathology, Medical Faculty, Wytemweg 2a, Postbus 1738, Rotterdam, The Netherlands.

Received for publication 2 April 1969.
65 Nigerian blood donors; from 35 Nigerian and 30 Jamaican paired maternal cord blood samples (postpartum); from 18 patients with multiple myeloma; and from 17 patients with malignaat lymphoma from Jamaica. The diagnosis $\bar{g} f$ multiple myeloma was made on bone marrow biopsy and confirmed biochemically and radiologically. The patients with malignant lymphonga were diagnosed by lymph node biopsy.

The myeloma patients were diagnosed between August 1966 and May 1967. The diagnosis wä̧ confirmed both radiologically and by botre marrow biopsy. The myeloma group consisted of eight women and 10 men and the ages ranged between 35 and 68 years.

Total protein, albumin, and globulin weise estimated by the biuret method and immunerglobulins by the single radial immunodiffusion method of Mancini, Vaerman, Garbonara, agd Heremans (1964) using both Beringwerke and Hyland immunoplates.

Immunoelectrophoresis was determined By the method of Scheidegger (1955) and Gm añid Inv groups by the method of Steinberg (1962)..$\rightleftharpoons$ 
The following reagents were used to determine the $\mathrm{Gm}$ and Inv antigens.

\begin{tabular}{|c|c|c|c|c|}
\hline \multirow[b]{2}{*}{ Antigen } & \multirow[b]{2}{*}{ Antibody } & \multicolumn{2}{|c|}{ Anti-Immunoglobulin } & \multirow{2}{*}{$\begin{array}{l}\text { Incomplete } \\
\text { Anti-D } \\
\text { Dilution }\end{array}$} \\
\hline & & Dilution & Anti-D & \\
\hline $\begin{array}{l}\text { Gm } 1 \\
\text { Gm } 3 \\
\text { Gm } 5 \\
\text { Gm } 6 \\
\text { Inv } 1\end{array}$ & $\begin{array}{l}\text { Wils } \\
\text { Ew } \\
\text { Dr } \\
\text { Wms } \\
\text { Math }\end{array}$ & $\begin{array}{l}1 / 4 \\
1 / 4 \\
1 / 8 \\
1 / 4 \\
1 / 4\end{array}$ & $\begin{array}{l}251 \\
\text { Jack } \\
3419 \\
\text { Warren } \\
\text { Roehm }\end{array}$ & $\begin{array}{l}1 / 3 \\
1 / 3 \\
1 / 10 \\
1 / 3 \\
9 / 10\end{array}$ \\
\hline
\end{tabular}

The samples from patients with multiple myeloma were tested for $\mathrm{Gm} \mathrm{1,} \mathrm{Gm} \mathrm{2,} \mathrm{Gm} \mathrm{3,} \mathrm{Gm} \mathrm{5,} \mathrm{and}$ Gm 6, and for Inv 1. To conserve reagents and the patients' sera, of which only small samples were available, sera from the myeloma patients were initially tested at $1 / 32$ dilution.

The samples from the lymphoma patients were tested only for $\mathrm{Gm} \mathrm{1,} \mathrm{Gm} \mathrm{3,} \mathrm{Gm} \mathrm{5,} \mathrm{and} \mathrm{Gm} 6$ at $1 / 16$ dilution. None of these samples was titrated.

\section{Results}

The results of immunoglobulin levels are summarized in Table I. The values for IgA were similar in various groups except in cord blood. The levels of IgG were significantly lower in all the Jamaican sera than in the corresponding Nigerian sera. The ratio of maternal to foetal IgG was 0.77 in the Jamaican but 1.09 in the Nigerians. Blood donor IgM in both groups was significantly lower than maternal IgM. Jamaican cord sera contained significantly less IgM than Nigerian cord sera.

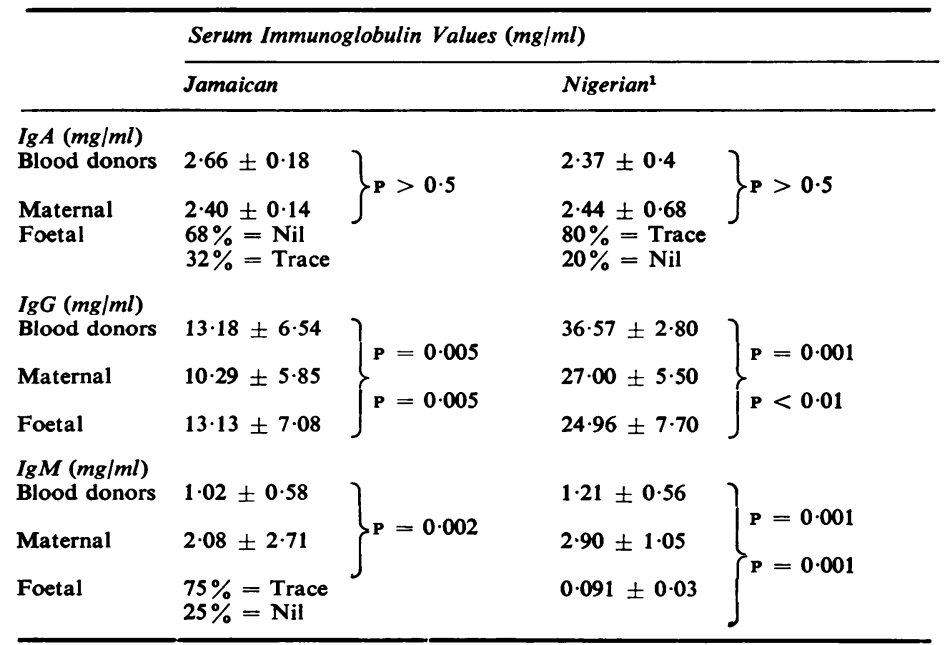

Table I Summary of serum immunoglobulin values ${ }^{1}$

${ }^{1}$ Modified from data given by McFarlane and Udeozo (McFarlane, H., and Udeozo, I. O. K. (1968). Arch. Dis. Childh., 43, 42).
Table II summarizes the findings in multiple ${ }^{c}$ myelomatosis. Here it can be seen that the age $\frac{\rho}{5}$. range was between 35 and 68 years. There was no $\tau$ difference in the sex distribution. Twelve of these $\stackrel{\oplus}{\rightleftharpoons}$ patients were of IgG type myeloma, five were of $\underline{\underline{\sigma}}$ IgA type, and in one patient (case 16) the serum $\stackrel{\Rightarrow}{\rightleftarrows}$ protein was of Bence-Jones type. Table II also $\stackrel{\overrightarrow{0}}{\rightarrow}$ shows that six of these patients had myeloma $\frac{}{2}$ protein of the lambda type light chain, whereas in 12 patients the myeloma protein was of the $\frac{\bar{N}}{\vec{D}}$ kappa type light chain. One patient (case 16, $\stackrel{\mathbb{Q}}{\varrho}$ Table II) may belong to that rare group of myelomatoses with a unique type of lambda $\overrightarrow{0}$ Bence-Jones proteinaemia of the disulphide $\stackrel{\circ}{-}$ dimer type recently referred to by Grey and $\vec{\omega}$ Kohler (1968). Eight of the 17 patients whose $\stackrel{\text { S }}{.}$ urines were tested gave a positive reaction for Bence-Jones proteins.

Antisera to determine the heavy chain sub-i types of the G myeloma protein were not avail- $\vec{N}$ able, and the results of the $\mathrm{Gm}$ determinations $\rightarrow$ were used to estimate the $\gamma$ chain subclass. Four 응 of the IgG myeloma samples (nos. 3, 4, 10, and 12) have a raised concentration of the Gm 1 क antigen. It is highly probable that this antigen is carried by the myeloma protein. One sample $\stackrel{\ulcorner}{\ulcorner}$ (no. 14) has a high titre of $\mathrm{Gm} 5$ and $\mathrm{Gm} \mathrm{6.} \vec{v}$ These antigens are probably carried by the myel-. oma protein. Kunkel, Allen, Grey, and Martensson (1964) and Terry, Fahey, and Steinberg (1965) have shown that $\mathrm{Gm} 1$ and $\mathrm{Gm} 3$ are carried by the $\gamma 1$ chain and that $\mathrm{Gm} 5$ and $\mathrm{Gm} 6$ are carried by the $\gamma 3$ chain. The $\mathrm{Gm}$ typing suggests that the $\underset{\Omega}{\mathbb{Q}}$ myeloma protein in samples $3,4,10,11,12$, and $\overrightarrow{\vec{F}}$ 13 has a $\gamma 1$ heavy chain, and that the heavy chain $\frac{3}{3}$ in sample 14 is $\gamma 3$. The heavy chain in the remaining samples may be either $\gamma 2$ or $\gamma 3$.

The Inv 1 titre of the sera is also shown in Table II. One sample (no. 14) had a high titre of Inv 1 but none of the others did.

Two of the myeloma patients (cases 3 and 16) showed the presence of $\mathrm{Gm} 3$ in their non-응 myeloma IgG protein, and this is evidence of white ancestry. No evidence of white ancestry was evident in any of the other samples. Similarly $\frac{}{0}$ in the group of 17 lymphoma patients, only two were observed with the $\mathrm{Gm}$ phenotype of mixed N white ancestry.

\section{Discussion}

Endemic malaria in Nigeria may be responsible $\stackrel{+}{+}$ for the higher concentrations of serum IgG in Nigerians than in Jamaicans and for the lower $\overrightarrow{\mathbb{D}}$ maternal-foetal IgG ratio in the Jamaicans. The $\frac{?}{\mathbb{C}}$ higher IgM level in the Nigerian foetal sera appears $\cong$ to support this hypothesis. The cause of the higher? IgM level in maternal blood than in donor blood is not known but similar results have been? reported by Rowe, McGregor, Smith, Hall, andô․ Williams (1968). 


\begin{tabular}{|c|c|c|c|c|c|c|c|c|c|c|c|c|}
\hline \multirow{2}{*}{$\begin{array}{l}\text { Case } \\
\text { No. }\end{array}$} & \multirow{2}{*}{$\begin{array}{l}\text { Age } \\
\text { (years) }\end{array}$} & \multirow{2}{*}{$\operatorname{Sex}$} & \multicolumn{5}{|c|}{ Type of Myeloma } & \multicolumn{4}{|c|}{ Gm Titre of Whole Serum } & \multirow[t]{2}{*}{$\ln v 1$} \\
\hline & & & $\begin{array}{l}\text { Immuno- } \\
\text { globulin }\end{array}$ & $\begin{array}{l}\text { Light } \\
\text { Chain }\end{array}$ & $\begin{array}{l}\text { Heavy } \\
\text { Chain }\end{array}$ & $G m$ & $\operatorname{In} v$ & 1 & 3 & 5 & 6 & \\
\hline 1 & 67 & $\mathbf{F}$ & $G$ & 1 & & & & $<32$ & $<32$ & $<32$ & $<32$ & $<32$ \\
\hline 2 & 57 & $\mathbf{M}$ & $\mathbf{A}$ & 1 & & & & $>32$ & $<32$ & $>32$ & $<32$ & $<32$ \\
\hline 3 & 62 & $F$ & $\mathrm{G}$ & $\mathbf{k}$ & 1 & 1 & & $>4096$ & 128 & 64 & $<32$ & $<32$ \\
\hline 4 & 47 & $\mathbf{M}$ & G & 1 & $i$ & 1 & & 2048 & $<32$ & 32 & $<32$ & 128 \\
\hline 5 & 35 & $\mathbf{M}$ & $\mathbf{A}$ & $\mathbf{k}$ & & & 1 & 256 & $<32$ & $<32$ & $<32$ & 64 \\
\hline 6 & 62 & $\mathbf{M}$ & A & $\mathbf{k}$ & & & & $>32$ & $<32$ & $>32$ & $<32$ & $<32$ \\
\hline 7 & 56 & $\mathbf{M}$ & A & $\mathbf{k}$ & & & & 256 & $<32$ & $<32$ & $<32$ & 64 \\
\hline 8 & 48 & $\mathbf{M}$ & $G$ & $\hat{\mathbf{k}}$ & & & & $<32$ & $<32$ & $<32$ & $<32$ & $<32$ \\
\hline 9 & 53 & $\mathbf{M}$ & G & $\mathbf{k}$ & & & & 64 & $<32$ & $<32$ & $<32$ & $<32$ \\
\hline 10 & 39 & $\mathbf{F}$ & G & $\mathbf{k}$ & 1 & 1 & & $>4096$ & $<32$ & $<32$ & $<32$ & $<32$ \\
\hline 11 & 46 & $\mathbf{F}$ & G & $\mathbf{k}$ & 1 & 1 & 1 & 512 & $<32$ & $<32$ & $<32$ & 512 \\
\hline 12 & 62 & $\mathbf{M}$ & $G$ & $\mathbf{k}$ & 1 & 1 & & $>4096$ & $<32$ & $<32$ & $<32$ & $<32$ \\
\hline 13 & 59 & $\mathbf{M}$ & $\mathbf{G}$ & $\mathbf{k}$ & 1 & 1 & 1 & 512 & $<32$ & 64 & $<32$ & 256 \\
\hline 14 & 52 & $\mathbf{F}$ & $G$ & $\mathbf{k}$ & 3 & 5,6 & 1 & $<32$ & $<32$ & $>4096$ & $>4096$ & 1024 \\
\hline 15 & 54 & $\mathbf{F}$ & A & $\hat{\mathbf{l}}$ & & & & 64 & $<32$ & $<32$ & $<32$ & $<32$ \\
\hline 16 & 53 & $\mathbf{F}$ & B. J. & 1 & & & & $>32$ & $>32$ & $>32$ & $<32$ & $<32$ \\
\hline 17 & 68 & $\mathbf{M}$ & G & $\mathbf{k}$ & & & & $\begin{array}{l}\text { Not } \\
\text { done }\end{array}$ & $\begin{array}{l}\text { Not } \\
\text { done }\end{array}$ & $\begin{array}{l}\text { Not } \\
\text { done }\end{array}$ & $\begin{array}{l}\text { Not } \\
\text { done }\end{array}$ & \\
\hline 18 & 53 & $\mathbf{F}$ & $\mathbf{G}$ & 1 & & & & $\begin{array}{l}\text { Not } \\
\text { done }\end{array}$ & $\begin{array}{l}\text { Not } \\
\text { done }\end{array}$ & $\begin{array}{l}\text { Not } \\
\text { done }\end{array}$ & $\begin{array}{l}\text { Not } \\
\text { done }\end{array}$ & \\
\hline
\end{tabular}

Table II Summary of findings in myeloma in Jamaicans

It is clear that ideal conditions for studying the incidence of multiple myeloma could best be achieved if the study were carried out over a longer period and/or if a large population survey in the island could be undertaken.

The types of myeloma in Jamaica are similar to those reported elsewhere. The proportion of kappa light chain type to lambda light chain type is similar to the proportion of these light chain types reported in other series of myeloma. The Gm titre of the sera showed that the majority of both the myeloma and lymphoma patients are of Negroid stock, and this suggests that the incidence of myeloma in Jamaica may not be due to mixed racial ancestry.

We should like to thank Miss M. O. Onabamiro, a medical student of the University of Ibadan, for technical assistance.

References

Camain, R., and Lambert, D. (1964). Les hématosarcomes en Afrique noire Occidentale et Centrale francophone. In The Lymphoreticular Tumours in Africa; A Symposium, edited by F. C. Roulet, pp. 42-53. Karger, Basle.

Davkes, J. N. P. (1964). Lymphomas and leukaemias in Uganda Africans. Ibid., pp. 67-79.
Edington, G. M., and McLean, C. M. U. (1964). The relative incidence of tumours of the reticulo-endothelial system is Ibadan, Nigeria. Ibid., pp. 54-66.

Edozien, J. C. (1957). The serum proteins of healthy adulf Nigerians. J. clin. Path., 10, 276-279.

Grey, H. M., and Kohler, P. F. (1968). A case of tetramer Benceeto Jones proteinaemia. Clin. exp. Immunol., 3, 277-285.

Kunkel, H. G., Allen, J. C., Grey, H. M., Martensson, L., and Grubb, R. (1964). A relationship between the $H$ chaip groups of $75 \gamma$-Globulin and the Gm system. Nature (Lond.), 203, 413-414.

MacMahon, B., and Clark, D. W. (1956). The incidence of mult iplę myeloma. J. chron. Dis., 4, 508-515.

McFarlane, H. (1966). Multiple myeloma in Jamaica: a study oळ్ 40 cases with special reference to the incidence and labora 8 tory diagnosis. J. clin. Path., 19, 268-271.

Mancini, G., Vaerman, G. P., Garbonara, A. O., and Heremans $\overrightarrow{\bar{D}}$ J. F. (1964). A single-radial-diffusion method for the immunological quantitation of proteins. Protides Biol. Fluids, 11, 370-373.

Mohun, A. F. (1946). Serum albumin and globulin levels ip?. Africans as compared with Europeans, with note off technique. Ann. trop. Med. Parasit., 40, 29-33.

Rowe, D. S., McGregor, I. A., Smith, S. J., Hall, P., and Williams K. (1968). Plasma immunoglobulin concentrations in के West African (Gambian) community and in a group of healthy British adults. Clin. exp. Immunol., 3, 63-79.

Scheidegger, J. J. (1955). Une micro-methode de l'immuno electrophorèse. Int. Arch. Allergy, 7, 103-110.

Steinberg, A. G. (1962). Evidence for a $\mathrm{Gm}$ allele negative for bot $\$$ Gm (a) and Gm (b). Vox Sang. (Basel), 7, 89-92.

Talerman, A. (1968). Unpublished.

Terry, W. D., Fahey, S. L., and Steinberg, A. G. (1965). Gm and Inv factors in subclasses of human IgG. J. exp. Med ì 122, 1087-1099. 